\title{
Evaluation of Job Stress and Work-related Health Concerns at a Telephone Call Center
}

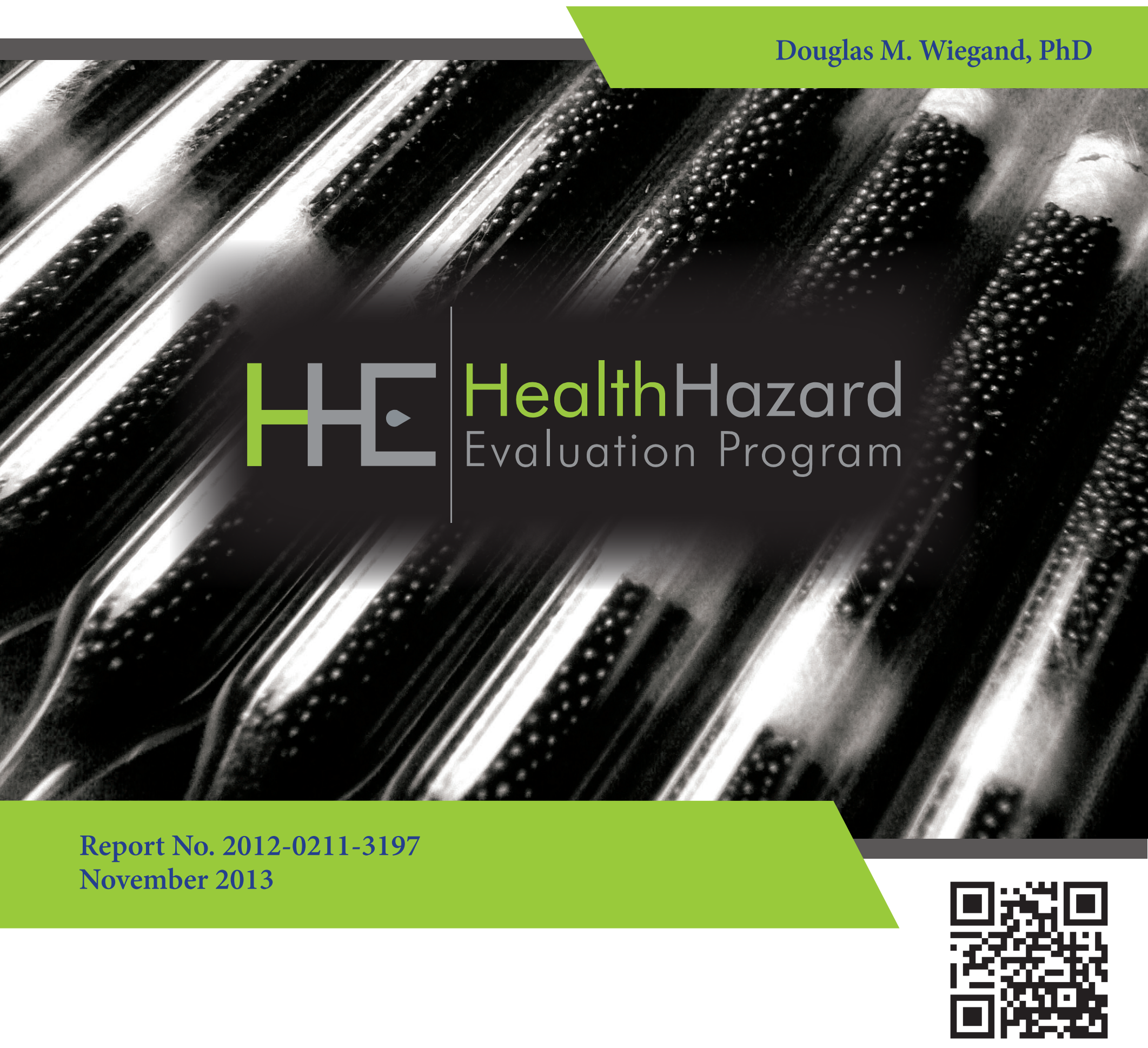

U.S. Department of Health and Human Services Centers for Disease Control and Prevention

National Institute for Occupational Safety and Health

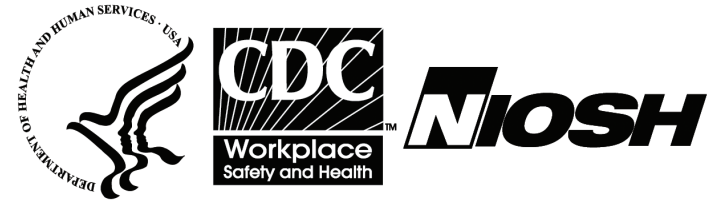




\section{Contents}

Highlights..............................................

Abbreviations .................................. iv

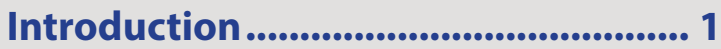

Methods .......................................... 1

Results ............................................ 3

Discussion $\ldots \ldots \ldots \ldots \ldots \ldots \ldots \ldots \ldots \ldots \ldots \ldots \ldots \ldots . \ldots . \ldots . \ldots . \ldots$

Conclusions ..................................... 9

Recommendations.................................. 9

References...................................... 11

Acknowledgements........................... 15

The employer is required to post a copy of this report for 30 days at or near the workplace(s) of affected employees. The employer must take steps to ensure that the posted report is not altered, defaced, or covered by other material.

The cover photo is a close-up image of sorbent tubes, which are used by the HHE Program to measure airborne exposures. This photo is an artistic representation that may not be related to this Health Hazard Evaluation. Photo by NIOSH. 


\section{Highlights of this Evaluation}

The Health Hazard Evaluation Program received a confidential request from employees at a telephone call center. The employees were concerned about psychosocial factors at work and the impact of job stress on their health.

\section{What We Did}

- We visited the telephone call center in January 2013.

- We surveyed employees about job stress, psychosocial factors at work, job satisfaction, work-related health concerns, and symptoms of depression and anxiety.

- We held a meeting with all employees to address questions and discuss mental health and suicide prevention.

\section{What We Found}

- Employees reported high job stress.

- Employees reported that workload and the demanding nature of the job contributed to stress.

- Job satisfaction was low. Most employees reported that they did not receive the respect they deserved and that their salary was inadequate relative to their efforts and achievements on the job.

- Employees reported work-related health concerns that included headaches/migraines, musculoskeletal strain, and health effects (e.g., allergy and cold symptoms) they attributed to poor indoor environmental quality.

- Depression and anxiety symptoms among employees were high.

We evaluated work organization, job stress, and health concerns at a telephone call center. Employees reported high job demands, low perceived job control, low job satisfaction, and high job stress. Depression and anxiety symptoms were common. We made administrative recommendations to reduce employees' workload and job stress and improve employee comfort at work.

\section{What the Employer Can Do}

- Engage employees in discussion about whether workload could be better managed and how. If feasible, hire more employees to reduce the number of calls employees must answer.

- Encourage employees to debrief with their supervisor or a coworker immediately after a call with an unfriendly customer.

- Program the telephone system to give a 6-second rest period between calls.

- Have a certified ergonomist set up the workstations for each employee or hold a training session to teach employees how to properly set up their own station.

- Maintain and clean the heating, ventilation, and air-conditioning units regularly.

- Follow a cleaning schedule for the entire facility. 


\section{What the Employees Can Do}

- Get emergency help immediately if you are thinking about harming yourself or someone else.

- Seek counseling if you are anxious, angry, depressed, or have other mental health problems. Get help from a licensed clinical psychologist or psychiatrist. 
This page left intentionally blank. 


\section{Abbreviations}

$\mathrm{NIOSH}$

PHQ-9

GAD-7
National Institute for Occupational Safety and Health

Patient health questionnaire (9 items)

General anxiety disorder scale (7 items) 


\section{Introduction}

The Health Hazard Evaluation Program received a confidential request from three employees at a telephone call center in New York. The employees were concerned about high workload and the impact of job stress on their health.

We evaluated the telephone call center in January 2013. The purpose of our evaluation was to (1) assess employees' level of job stress and associated stressors, (2) assess employees' perceptions of psychosocial factors at work and their association with job stress, (3) assess employees' job satisfaction, (4) assess employees' work-related health concerns, (5) screen employees for symptoms of depression and anxiety, and (6) provide recommendations to mitigate job stress and address employees' work-related health concerns.

\section{Center Description}

The call center was one of many offices in a large federal building in a downtown urban area. Approximately 50 call center employees assisted callers with matters related to U.S. citizenship and immigration services and benefits. The center reportedly received 2,000-5,000 calls per day. This facility handled calls that required additional information or assistance beyond that provided by other facilities. Employees were on the telephone for most of their shift while simultaneously searching for and inputting information into computer programs. Employees were encouraged to keep their call handling time to under 8 minutes per call, and the phone system that assigned calls was supposed to allow employees an automatic rest period of 6 seconds between calls. Employees were allowed two 15-minute breaks in addition to a 30-minute lunch break during their 8-hour shift. A 2-hour "shut down" period once a week allowed employees time to complete training or attend to other job tasks without handling telephone calls. Employees participated in town hall style meetings every 6 weeks to discuss updates, training, and employee concerns.

\section{Methods}

We distributed a self-administered, anonymous survey along with instructions and information about participant confidentiality to the desks of all 43 present employees who handled telephone calls. Participants were asked to seal their completed survey in an envelope and return it directly to a National Institute for Occupational Safety and Health (NIOSH) investigator. The survey included scaled and open-ended items and covered participant demographics, job stress, psychosocial factors at work, job satisfaction, workrelated health concerns, and symptoms of depression and anxiety.

\section{Job Stress}

We asked participants to rate their level of job stress with the following survey item: "During the past week, including today, how would you rate your current job stress level on a scale from 0 (as low as it can be) to 10 (as high as it can be)?" [Clark et al. 2011]. We also asked 
participants to "describe the major sources of job stress in your current occupation" in an open-ended question.

\section{Psychosocial Factors at Work}

We asked participants to rate their level of agreement with 15 statements describing psychosocial factors at work on a scale from 1 (strongly disagree) to 5 (strongly agree). The psychosocial factors included job demands, perceived job control, safety communication and climate, and social support. Job satisfaction was measured using the same five-point scale. Survey items for these factors were selected from validated measures deemed appropriate for health hazard evaluations [Wiegand et al. 2012].

We explored the relationships between employees' ratings of the psychosocial factors and ratings of job stress. We calculated Cronbach's alpha coefficients to determine whether the items within each of the psychosocial factors (job demands, perceived job control, safety climate and communication, and social support) were measuring the same general concept. Composite scores for each factor that had a Cronbach's coefficient of $\alpha>0.7$ were calculated by computing the averages of the items within the factor. Some survey items were reverse scored when necessary. Linear regression analyses were used to determine which of these factors were independently associated with job stress.

\section{Work-related Physical Health Concerns}

In an open-ended question we asked participants to describe "any health problems that you think may be related to your work."

\section{Depression}

We screened employees for symptoms of depression using the Patient Health Questionnaire 9 (PHQ-9) [Kroenke et al. 2001]. The PHQ-9 is a nine-item measure designed to establish a provisional diagnosis of major depressive disorder. Each item is framed to determine how often the participant had experienced symptoms of depression over the past 2 weeks. Items were scored by assigning a number $0-3$ on the basis of the following response options: not at all, several days, more than half the days, and nearly every day. A total depression severity score (ranging from 0 to 27) was calculated by summing the item scores. Clinical cutoff points are 5 (mild), 10 (moderate), 15 (moderately severe), and 20 (severe) [Kroenke et al. 2010].

\section{Anxiety}

We screened employees for symptoms of anxiety using the General Anxiety Disorder 7 (GAD-7) questionnaire [Spitzer et al. 2006]. The GAD-7 is a seven-item measure designed to establish a provisional diagnosis of generalized anxiety disorder. Similar to the PHQ-9, participants were asked to report how often they had experienced symptoms of anxiety over the past 2 weeks. Items were scored by assigning a number $0-3$ on the basis of the following response options: not at all, several days, more than half the days, and nearly every day. A 
total anxiety severity score (ranging from 0 to 21 ) was calculated by summing the item scores. Clinical cutoff points are 5 (mild), 10 (moderate), and 15 (severe) [Spitzer et al. 2006].

\section{Results}

We received 38 of 43 (88\%) of the surveys we distributed. Sixty-three percent (17/27) of respondents were female, $63 \%(22 / 35)$ were between the ages of 26 and 44, and $61 \%(22 / 36)$ had been working at the call center for 5 years or less.

\section{Job Stress}

All employees reported a job stress score of 5 or greater; $46 \%(17 / 37)$ rated their job stress at the highest level of 10 (one participant did not rate their stress level). The median job stress score was $9(\mathrm{~N}=37)$. Job stressors reported by five or more employees in response to an open-ended question are listed in Table 1.

\begin{tabular}{lc}
$\begin{array}{l}\text { Table 1. Major sources of job stress in current position } \\
(\mathrm{N}=38)\end{array}$ & $\begin{array}{c}\text { Employees reporting } \\
\text { number }(\%)\end{array}$ \\
\hline Job stressor & $23(61)$ \\
\hline Workload/number of calls & $18(47)$ \\
Inadequate breaks & $13(34)$ \\
Interacting with angry or rude callers & $12(32)$ \\
Being micromanaged & $8(21)$ \\
Time constraints on calls & \\
\hline
\end{tabular}

The reported stressors were related to the demanding nature of the job, which required employees to assist customers on the phone for nearly their entire shift while keeping the conversations to 8 minutes or less. Many of the employees who reported that call volume was a source of job stress mentioned that they had little to no time in between the calls. The phone lines were regulated by a computer program that was supposed to allow a buffer period of at least 6 seconds between calls assigned to employees, but employees reported they would often have a call waiting for them immediately after hanging up from their previous call. Employees reported that it was stressful to interact with angry or rude customers and then have little time to regain their composure before accepting the next call in their queue. Nearly half of the employees reported inadequate lunch and bathroom breaks as job stressors and factors that may adversely affect their health (e.g., having to "hold their bladder too long" and having "indigestion from eating quickly"). Employees reported that they could only use the bathroom during their 15-minute breaks. Some employees reported having to skip their breaks to keep up with their workload. 


\section{Psychosocial Factors at Work}

We asked participants to rate their level of agreement with 15 statements describing psychosocial factors at work on a scale from 1 (strongly disagree) to 5 (strongly agree). Table 2 shows the percentage of employees who agreed with each item by indicating a 4 or 5 on the scale, as well as the average score for each item.

Table 2. Employees $(n=35-38)$ rating psychosocial factors at work*

\begin{tabular}{|c|c|c|}
\hline Psychosocial Items & $\begin{array}{c}\text { Number of } \\
\text { employees } \\
(\%) \text { reporting } \\
\text { agreement (4 or } 5 \\
\text { on } 5 \text {-point scale) }\end{array}$ & $\begin{array}{l}\text { Average } \\
\text { score }\end{array}$ \\
\hline \multicolumn{3}{|l|}{ Job demands } \\
\hline $\begin{array}{l}\text { I am often required to work for long periods with my body in } \\
\text { physically awkward positions. }\end{array}$ & $18(49)$ & 3.3 \\
\hline I have constant time pressure due to a heavy work load. & $29(76)$ & 4.3 \\
\hline $\begin{array}{l}\text { I have many interruptions and disturbances while performing } \\
\text { my job. }\end{array}$ & $19(50)$ & 3.4 \\
\hline Over time, my job has become more and more demanding. & $27(71)$ & 4.1 \\
\hline \multicolumn{3}{|l|}{ Perceived job control } \\
\hline I am given a lot of freedom to decide how to do my own work. & $4(11)$ & 1.9 \\
\hline I am given a lot of freedom to decide the amount of work I do. & $0(0)$ & 1.4 \\
\hline $\begin{array}{l}\text { I am given a lot of freedom to decide the pace of my work, that } \\
\text { is, how fast or slow I work. }\end{array}$ & $2(5)$ & 1.4 \\
\hline $\begin{array}{l}\text { I am allowed adequate breaks during my shift to stretch, rest } \\
\text { my eyes, etc. }\end{array}$ & $2(5)$ & 1.5 \\
\hline I get to do a variety of different tasks on my job. $†$ & $5(14)$ & 1.8 \\
\hline \multicolumn{3}{|l|}{ Safety communication and climate } \\
\hline $\begin{array}{l}\text { There is open communication about health and safety issues } \\
\text { within this workplace. }\end{array}$ & $7(19)$ & 2.2 \\
\hline $\begin{array}{l}\text { Employees are regularly consulted about workplace health } \\
\text { and safety issues. }\end{array}$ & $5(14)$ & 2.1 \\
\hline $\begin{array}{l}\text { My supervisor is concerned about the welfare of those under } \\
\text { him/her. } \dagger\end{array}$ & $22(59)$ & 3.6 \\
\hline \multicolumn{3}{|l|}{ Social support } \\
\hline The people I work with (my coworkers) are friendly. & $27(73)$ & 4.2 \\
\hline $\begin{array}{l}\text { The people I work with (my coworkers) are helpful in getting } \\
\text { the job done. }\end{array}$ & $26(70)$ & 4.1 \\
\hline I am exposed to hostility or conflict from my supervisor(s). $\dagger$ & $7(19)$ & 2.0 \\
\hline
\end{tabular}

*Scale: 1 (strongly disagree) to 5 (strongly agree)

†ttem removed from the factor's composite score to improve the reliability coefficient of the items

Employees reported that their job was demanding because of a heavy work load and that over time the job had become increasingly more demanding. Employees reported low perceptions of job control in terms of how they did their work, the amount of work they did, and the pace in which they did their work. Most employees believed communication regarding health and safety issues in the workplace was lacking and that employees were not regularly consulted regarding these issues. Most employees reported that their coworkers were friendly and helpful. 


\section{Factors Associated with Job Stress}

Simple linear regression models showed a statistically significant positive relationship between job demands and job stress $(P<0.01)$, meaning as demands increase so does job stress. The models also showed a significant negative relationship between perceived job control and job stress $(P<0.01)$, meaning as job control decreases, job stress increases. Social support and safety communication and climate were not statistically related to job stress. When job demands and perceived job control were entered into a multivariate linear regression model, only the job demands composite remained significant $(P<0.05)$.

\section{Job Satisfaction}

We asked participants to rate their level of agreement with five statements designed to examine job satisfaction on a scale from 1 (strongly disagree) to 5 (strongly agree). Table 3 shows the percentage of employees who agreed with each item by indicating a 4 or 5 on the scale and the average score for each item.

Table 3. Job satisfaction items $(\mathrm{N}=37)^{\star}$

\begin{tabular}{lcc}
\hline & $\begin{array}{c}\text { Number of } \\
\text { employees } \\
(\%) \text { reporting } \\
\text { agreement (4 or 5 } \\
\text { on 5 point scale) }\end{array}$ & $\begin{array}{c}\text { Average } \\
\text { score }\end{array}$ \\
\hline I receive the respect I deserve at work. & $11(30)$ & 2.9 \\
My job promotion prospects are poor. & $20(54)$ & 3.6 \\
I have experienced or I expect to experience an undesirable & $23(62)$ & 3.7 \\
change in my work situation. & $6(16)$ & 2.2 \\
$\begin{array}{l}\text { My job security is poor. } \\
\text { Considering all my efforts and achievements, my salary/income }\end{array}$ & $11(31)$ & 2.7 \\
is adequate. $(\mathrm{N}=35)$ & & \\
\hline
\end{tabular}

*Scale: 1 (strongly disagree) to 5 (strongly agree)

Thirty percent of employees reported that they got the respect they deserved at work, and a similar percentage believed that their salary was adequate considering their efforts and achievements at work. Although few employees reported that their jobs were not secure, more than half believed their promotion prospects were poor.

\section{Work-related Health Concerns}

We asked participants to describe any health problems that they believed were related to their work. Thirty employees reported work-related health concerns. Work-related health concerns reported by five or more employees are listed in Table 4 . The most commonly reported work-related health concerns were frequent migraines/headaches (generally thought by the employees to be due to staring at a computer monitor for long periods), indoor environmental quality concerns (perceived poor air quality and circulation, exposure to dust, dirt, and mold) believed to be associated with cold and allergy symptoms, and musculoskeletal pain (mainly from long periods of sitting and using a keyboard). 
Table 4. Frequency of reported work-related health concerns $(\mathrm{N}=38)$

\begin{tabular}{lc}
\hline Concern & $\begin{array}{c}\text { Employees reporting } \\
\text { number (\%) }\end{array}$ \\
\hline Migraines/headaches & $14(37)$ \\
$\begin{array}{l}\text { Indoor environmental quality impacting } \\
\text { health }\end{array}$ & $9(24)$ \\
Musculoskeletal pain & $8(21)$ \\
No work-related health concern(s) & $8(21)$ \\
reported & $6(16)$ \\
Anxiety & $6(16)$ \\
Sleep-related problems & $5(13)$ \\
Hypertension (believed to be stress & \\
related) & \\
\hline
\end{tabular}

\section{Mental Health}

\section{Depression Symptoms Severity Score Results}

Figure 1 shows the proportions of employees by depression severity score cut-off levels. These proportions may be somewhat underestimated because seven participants skipped one or two PAH-9 items. Forty-five percent reported moderate to severe symptoms.

We explored which psychosocial factors at work were associated with reported depression symptoms. We used the mean composite scores for the psychosocial factors and the total PHQ-9 score. Simple linear regressions showed that job demands had a positive relationship

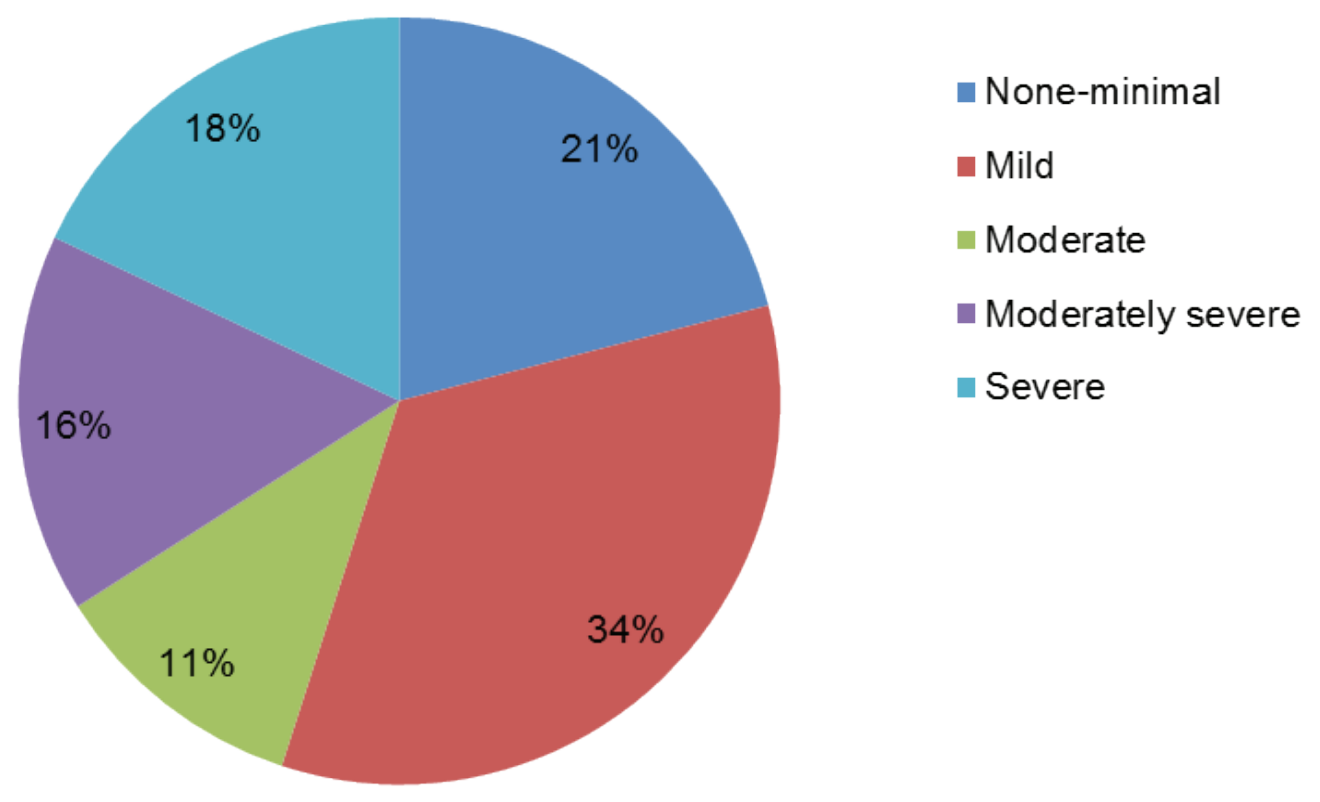

Figure 1. Depression symptoms severity score results $(\mathrm{N}=38)$. 
with symptoms of depression $(P<0.01)$, meaning higher job demands were associated with increased depression severity. Perceived job control $(P<0.01)$ had negative relationships with symptoms of depression, meaning lower perceived job control was associated with increased depression severity. Social support and safety communication were not statistically associated with depression. When the two statistically significant factors were entered into a multiple linear regression model, perceived job control $(P<0.05)$ remained significant, while job demands did not.

\section{Anxiety Symptoms Severity Score Results}

Figure 2 shows the proportions of employees by anxiety severity level. As with symptoms of depression, the proportions of each severity level of anxiety may be somewhat underestimated because six participants skipped one or more GAD-7 items. Thirty-nine percent reported moderate to severe symptoms of anxiety.

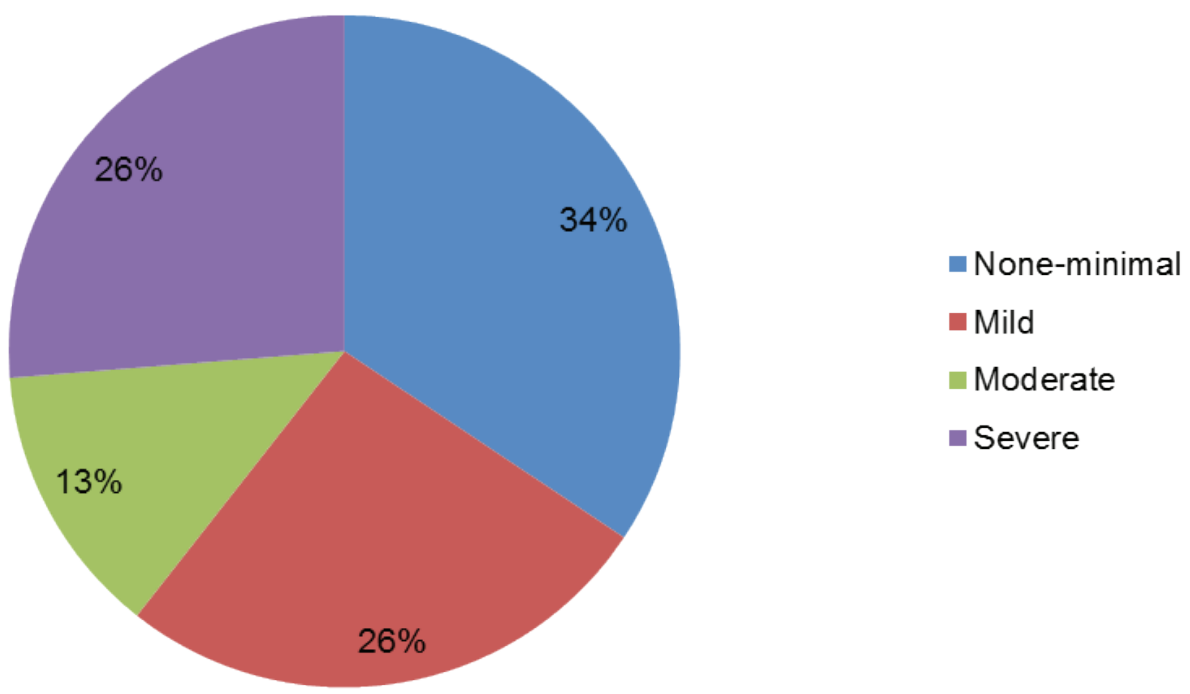

Figure 2 . Anxiety symptoms severity score results $(\mathrm{N}=37)$.

We explored which psychosocial factors at work were associated with symptoms of anxiety. We used the mean composite scores for the psychosocial factors and the total GAD-7 score. Simple linear regression models showed that job demands $(P<0.05)$ had a positive relationship with symptoms of anxiety (i.e., higher job demands were associated with increased anxiety severity), while perceived job control $(P<0.001)$ and safety communication $(P=0.01)$ had negative relationships with symptoms of anxiety (i.e., lower ratings of these factors were associated with increased anxiety severity). Social support was not significantly associated with anxiety. When the three statistically significant psychosocial factors were entered into a multiple linear regression model, only job control $(P<0.01)$ remained significant. 


\section{Town Hall Meeting with Employees}

We assembled all present employees for a town hall style meeting to discuss their health and safety concerns. We also encouraged employees to seek mental health counseling if they were experiencing symptoms of depression or anxiety that were interfering with their ability to function at work, at home, or socially. We urged anyone having suicidal thoughts to immediately seek help from a mental health professional and provided information on the Federal Occupational Health Employee Assistance Program.

Employees mainly voiced concerns regarding the physical working environment (air circulation and quality, indoor temperature, inadequate lighting, and cleanliness of working areas), ergonomics, consecutive calls without a brief buffer period of 6 seconds, and the perception that a lunch period of 30 minutes is inadequate and unhealthy. Concerns regarding the physical working environment were not included in the health hazard evaluation request, and were not included in this evaluation. Employees were encouraged to submit a new health hazard evaluation request to evaluate the physical working environment.

\section{Discussion}

NIOSH defines job stress as the harmful physical and emotional responses that occur when job demands do not match the capabilities, resources, or needs of employees [NIOSH 2011]. In prior health hazard evaluations at call centers the HHE Program found that many employees experience a high workload, face hostility or abuse from customers, and report being physically and mentally exhausted at the end of their workday [NIOSH 1994, 2007a,b, 2012]. These job stressors have been found consistently in the call centers we have evaluated.

Reported job stress was high at this call center (median score of 9 out of 10). No employees reported a job stress score below 5, and the most frequently reported score was the maximum stress level of 10. As a comparison, in a recent NIOSH health hazard evaluation with employees of a similar call center (call center B), the median job stress score was 7, with $23 \%(64 / 279)$ of employees rating their job stress level below a score of 5 on the same scale [NIOSH 2012]. Call center B reported similar work-related concerns and job stressors (e.g., workload, time pressure, interacting with hostile customers), though these were not as prominent as with this call center.

Seventeen (45\%) employees reported moderate to severe symptoms of depression and fifteen (39\%) employees reported moderate to severe symptoms of anxiety in the prior 2 weeks. The annual prevalence rates of major depressive disorder and generalized anxiety disorder among U.S. adults are 7\% and 2.9\%, respectively [American Psychiatric Association 2013]. These rates, however, cannot be directly compared with our findings because they are based on actual diagnosed cases whereas our findings were based on a screening tool. Individuals who believe they are experiencing symptoms of depression and/or anxiety should seek a diagnosis and other guidance from their primary care physician or a counselor from the Federal Occupational Health Employee Assistance Program. 


\section{Follow-up Actions}

We provided initial recommendations in a post-evaluation letter to the call center management and employee representative in January 2013. Actions taken by the call center management to address these recommendations include:

1. In January 2013, a representative of the Federal Occupational Health Employee Assistance Program visited the call center to discuss psychological services available to the call center employees. In February 2013, employees received training in suicide prevention from the Employee Assistance Program.

2. A U.S. General Services Administration technician inspected the ventilation systems for the call center and repaired a broken fan in January 2013.

3. Facilities managers visited the call center in January 2013 to assess the need for and prepare bids for painting, lighting, rugs and ergonomically correct furniture (in compliance with Federal Occupational Health guidelines).

4. Federal Occupational Health was contacted to schedule ergonomic training for employees to properly set up their work stations.

5. A certified industrial hygienist employed by Federal Occupational Health assessed indoor air quality at the call center in March 2013.

\section{Conclusions}

Reported job stress was high at this workplace, which we found to be related to employees' perceptions of high workload and low perceived job control. The high prevalence of symptoms consistent with depression and anxiety were also associated with high ratings of job demands and low ratings of perceived job control.

\section{Recommendations}

On the basis of our findings, we recommend the actions listed below. We encourage the call center to use a labor-management health and safety committee or working group to discuss our recommendations and develop an action plan. Those involved in the work can best set priorities and assess the feasibility of our recommendations for the specific situation at the call center.

1. Evaluate employee workload and obtain employee input regarding the volume of calls they receive daily and how it affects job stress, job satisfaction, and job control. Engage employees in discussion about whether workload could be better managed and how. Doing so can improve employee morale and perceptions of personal control.

2. Hire additional employees to reduce the call volume for individuals and to allow more opportunities for employees to have a brief rest period between calls to stand, stretch, or rest their eyes. 
3. Update the telephone system if needed to provide a requisite 6-second rest period between calls.

4. Provide training/educational materials to employees that encourage anyone having thoughts of harming themselves or others to immediately seek emergency help through local health providers, emergency rooms, or suicide prevention hotlines such as the National Suicide Prevention Lifeline at (800) 273-8255. These materials should be readily accessible to employees at all times.

5. Encourage employees to seek the help from a qualified health professional if they are experiencing symptoms of depression, anxiety, or other mental health disorders that are interfering with their social, occupational, or other important areas of functioning. One resource for employees is the Federal Occupational Health Employee Assistance Program at (800) 222-0364 or http://www.foh4you.com/.

6. Contact the employee assistance program to arrange for a mental health professional to give an annual training or educational presentation about suicide prevention. The Suicide Prevention Resource Center has helpful resources for managers at http://www. sprc.org/sites/sprc.org/files/Employers.pdf. The National Institute of Mental Health also has resources on their suicide prevention topic page at http://www.nimh.nih.gov/ health/topics/suicide-prevention/index.shtml.

7. Encourage employees who interact with a particularly hostile customer on the phone to immediately debrief with their supervisor or another coworker following the call. This practice may boost social support and have a buffering effect on job stress.

8. Ask a certified industrial hygienist to evaluate the heating, ventilation, and airconditioning unit(s) in the building to determine if they are balanced and well maintained.

9. Ask a certified industrial hygienist familiar with lighting recommendations to evaluate the indoor lighting to determine if brighter lighting is appropriate.

10. Ask a certified ergonomist to set up the workstations for each employee, or hold a training session to teach employees how to properly set up their own station. We recommend buying adjustable equipment that can accommodate $90 \%$ of employees.

11. Work with the housekeeping contractors to prepare and follow written procedures that detail a fixed and comprehensive cleaning schedule for the entire facility as well as the proper use and storage of cleaning products. The use of vacuums equipped with highefficiency particulate air filters will reduce the levels of fine or small airborne particles or dust. Annual steam cleaning of materials that are not vacuumed regularly (e.g., curtains) will also improve indoor environmental quality. Inadequate housekeeping can contribute to indoor environmental quality problems. Additional information can be found at http://www.cdc.gov/niosh/docs/98-123/step5.html. 


\section{References}

American Psychiatric Association [2013]. Diagnostic and statistical manual of mental disorders, 5th ed. Arlington, VA: American Psychiatric Association.

Clark MM, Warren BA, Hagen PT, Johnson BD, Jenkins SM, Werneburg BL, Olsen KD [2011]. Stress level, health behaviors, and quality of life in employees joining a wellness center. Am J Health Promot 26(1):21-25.

Kroenke K, Spitzer RL, Williams JB [2001]. The PHQ-9: validity of a brief depression severity measure. J Gen Intern Med 16(9):606-613.

Kroenke K, Spitzer RL, Williams JB, Löwe B [2010]. The patient health questionnaire somatic, anxiety, and depressive symptom scales: a systematic review. Gen Hosp Psychiatry 32(4):345-359.

NIOSH [1994]. Health hazard evaluation report: Social Security Administration Teleservice Centers - Boston, Massachusetts, Fort Lauderdale, Florida. Cincinnati, OH: U.S. Department of Health and Human Services, Centers for Disease Control and Prevention, National Institute for Occupational Safety and Health, NIOSH HETA Report No. 92-0382-2450.

NIOSH [2007a]. Health hazard evaluation report: Cincinnati Police Department, Police Communication Section - Cincinnati, Ohio. Cincinnati, OH: U.S. Department of Health and Human Services, Centers for Disease Control and Prevention, National Institute for Occupational Safety and Health, NIOSH HETA Report No. 99-0199-3053.

NIOSH [2007b]. Health hazard evaluation report: New York City Police Department, Police Communications Section - New York, New York. Cincinnati, OH: U.S. Department of Health and Human Services, Centers for Disease Control and Prevention, National Institute for Occupational Safety and Health, NIOSH HETA Report No. 97-0137-3026.

NIOSH [2011]. Work organization and stress-related disorders. [http://www.cdc.gov/niosh/ programs/workorg/]. Date accessed: November 2013.

NIOSH [2012]. Health hazard evaluation report: lighting, indoor environmental quality concerns and job stress at a call center - California. By Wiegand D, Ramsey J, Burr G, Choi J. Cincinnati, OH: U.S. Department of Health and Human Services, Centers for Disease Control and Prevention, National Institute for Occupational Safety and Health, NIOSH HETA Report No. 2012-0081-3169.

Spitzer RL, Kroenke K, Williams JBW, Lowe B [2006]. A brief measure for assessing generalized anxiety disorder: the GAD-7. Arch Intern Med 166(10):1092-1097. 
Wiegand DM, Chen PY, Hurrell JJ Jr., Jex S, Nakata A, Nigam J, Robertson M, Tetrick L [2012]. A consensus method for updating psychosocial measures used in NIOSH health hazard evaluations. J Occup Environ Med 54(3):350-355. 
This page left intentionally blank. 
Keywords: North American Industry Classification System 923130 (Administration of Human Resource Programs [except Education, Public Health, and Veterans' Affairs Programs]), call center, job stress, work organization, mental health 
The Health Hazard Evaluation Program investigates possible health hazards in the workplace under the authority of the Occupational Safety and Health Act of 1970 (29 U.S.C. § 669(a)(6)). The Health Hazard Evaluation Program also provides, upon request, technical assistance to federal, state, and local agencies to investigate occupational health hazards and to prevent occupational disease or injury. Regulations guiding the Program can be found in Title 42, Code of Federal Regulations, Part 85; Requests for Health Hazard Evaluations (42 CFR Part 85).

\section{Disclaimer}

The recommendations in this report are made on the basis of the findings at the workplace evaluated and may not be applicable to other workplaces.

Mention of any company or product in this report does not constitute endorsement by the National Institute for Occupational Safety and Health (NIOSH).

Citations to Web sites external to NIOSH do not constitute NIOSH endorsement of the sponsoring organizations or their programs or products. NIOSH is not responsible for the content of these Web sites. All Web addresses referenced in this document were accessible as of the publication date.

\section{Acknowledgments}

Desktop Publishers: Mary Winfree

Editor: Ellen Galloway

Health Communicator: Stefanie Brown

Logistics: Donnie Booher and Karl Feldmann

\section{Availability of Report}

Copies of this report have been sent to the employer, employees, and union at the call center. The state and local health department and the Occupational Safety and Health Administration Regional Office have also received a copy. This report is not copyrighted and may be freely reproduced.

This report is available at http://www.cdc.gov/niosh/hhe/reports/pdfs/2012-0211-3197.pdf.

Recommended citation for this report:

NIOSH [2013]. Health hazard evaluation report: evaluation of job stress and work-related health concerns at a telephone call center. By Wiegand DM. Cincinnati, OH: U.S. Department of Health and Human Services, Centers for Disease Control and Prevention, National Institute for Occupational Safety and Health, NIOSH HETA Report No. 2012-02113197. 
Delivering on the Nation's promise:

Safety and health at work for all people through research and prevention

To receive NIOSH documents or more information about occupational safety and health topics, please contact NIOSH:

Telephone: 1-800-CDC-INFO (1-800-232-4636)

TTY: 1-888-232-6348

CDC INFO: www.cdc.gov/info

or visit the NIOSH Web site at www.cdc.gov/niosh

For a monthly update on news at $\mathrm{NIOSH}$, subscribe to NIOSH eNews by visiting www.cdc.gov/niosh/eNews. 